\title{
Biochemical studies in Oreochromis niloticus exposed to lead acetate and treated by carob or fig ether extracts
}

\author{
Adel M .E . Shalaby ${ }^{1}$ Ahmed A. Said ${ }^{2}$, Mohamed H. Kairy ${ }^{2}$, Hazem \\ Thabet Ismail ${ }^{1}$. \\ ${ }^{1}$ Fish Physiology Departement, Central Laboratory for Aquaculture \\ Research, Abbassa, Abo Hammad, Sharkia ,Egypt. \\ ${ }^{2}$ Pharmacological Departement, Faculty of Veterinary Medicine, \\ Zagazig University, Egypt.
}

\begin{abstract}
The effect of carob pods (Ceratonia siliqua) and fig fruits (ficus carica) ether extracts $600 \mathrm{mg} / \mathrm{kg}$ in the diet against sublethal doses of $\mathrm{Pb}\left(1 / 2\right.$ and $\left.1 / 4 \mathrm{LC}_{50}\right)$ on aspartate amino transferase (AST), alanine amino transferase (ALT), urea , creatinine and accumulation of lead in muscle and visceral organs in (Oreochromis niloticus) was investigated .The half lethal concentration $\left(\mathrm{LC}_{50}\right)$ for $96 \mathrm{hr}$ was $155 \mathrm{mg} / \mathrm{l}$. Results showed that aspartate amino transferase (AST), alanine amino transferase (ALT), urea , creatinine and accumulation of lead in muscle and visceral organs was increased after exposed to $1 / 2 \mathrm{LC}_{50}$ and $1 / 4 \mathrm{LC}_{50}$ of $\mathrm{Pb}$ for 30,60 and 90 days. On the other hand $O$. niloticus exposed to $1 / 2 \mathrm{LC}_{50}$ and $1 / 4 \mathrm{LC}_{50}$ of $\mathrm{Pb}$ and fed with diet contain $600 \mathrm{mg}$ of carob extract $/ \mathrm{kg}$ for 90 days showed no significant changes in creatinine, accumulation of lead in muscle and visceral . Also the fish exposed to $1 / 2 \mathrm{LC}_{50}$ and $1 / 4 \mathrm{LC}_{50}$ of $\mathrm{Pb}$ and fed with diet contain $600 \mathrm{mg}$ of fig extract $/ \mathrm{kg}$ for 90 days revealed no significant changes in AST, ALT, urea, creatinine, accumulation of lead in muscle and visceral organs.It could be concluded that both carob and fig ether extracts had ameliorative effect against lead acetate toxicity in Oreochromis niloticus.
\end{abstract}

\section{Introduction}

Lead $(\mathrm{Pb})$ exposure is considered to be a major public health problem, therefore it has been paid attention by researchers in probing further into its toxicity. This heavy metal has been found to induce a wide range of behavioral, biochemical and physiological effects. The liver, kidneys, and 
brain are considered to be the target organs for the toxic effects of lead (Sharma and Street 1980 and Jackie et al., 2011).

Shalaby 2006 and 2007 showed that the Oreochromis exposed to heavy metals (chromium, cadmium ) induced physiological and biochemical changes.

Plants are considered as store house and a sources of many safer and cheaper chemicals. Plant derived compounds such as alkaloids, flavonoids, pigments, phenolics, terpenoids, steroids and essential oils have been reported to promote various activities like antistress, growth promotion, appetite stimulation, tonic and immunostimulation, and antimicrobial properties in fish culture (Citarasu 2010).

Herbal medicine have been used for thousands of years to improve the health. Even in the areas where modern medicines are available, the interest on herbal medicines and the utilization has been increasing rapidly in recent years. Herbal medicines have acceptable quality, safety and efficacy. Herbal therapies had become an integral part of health care science. Their pharmaceutical products used in conventional practice were derived from plants. There is a growing interest about the benefit of using crude plant extract containing mixtures rather a single. In the usage of herbal medicines the information regarding safety regulations, toxicity and hazard identifications are needed to improve its usage ( Tapsell and Cobiac, 2006).

One of the important and well documented uses of plant products is their use as hepatoprotective agents. Hence there is an ever increasing need for safe hepatoprotective agent (Roy et al .,2012).

A large number of medicinal plants such as carob and fig have been tested and found to contain active principles with curative properties against a variety of diseases. The plants contain a variety of chemical constituents like monoterpenes, carotinoids, glycosides, flavonoids, organic acids and xanthenes which enhance the liver protection in fish . Therefore, a large number of plants and formulations have been supposed to have hepatoprotective activity (Kumar 2012).

The need for high quality fish seed has necessitated research into various ways of enhancing fertility to meet the growing demand. However the continuing expansion of aquaculture requires shifting from synthetic drugs to natural plant. Medicinal plants that were once considered of no value are now being investigated, evaluated and 
developed into drugs with little or no side effects on the organisms (Adedeji et al.,2006).

Carob (Ceratonia siliqua) and fig (Ficus carica) contain active principles with curative characters against several diseases such as monoterpenes, carotinoids, glycosides, flavonoids, organic acids and xanthenes (Roy et al .,2012). Carob interfered with the absorption of lead (Bosscher et al., 2001).Also fig is achelating agent for lead ions (Aziz 2012 ).

The extract of the ficus carica. was evaluated for hepatoprotective activity in rats with liver damage induced by carbon tetrachloride. The extract at an oral dose of $500 \mathrm{mg} / \mathrm{kg}$ exhibited a significant protective effect by lowering the serum levels of aspartate aminotransferase, alanine aminotransferase, total serum bilirubin, and malondialdehyde equivalent an index of lipid peroxidation of the liver. The methanolic extract of Ficus carica administered prophylactically exhibited significant protection against $\mathrm{CCl} 4$ induced liver damage (Krishna et al., 2007).

The present study was designed to evaluate the possible positive impact of Ceratonia siliqua (carob) pods and ficus carica (fig) fruits ether extracts against lead toxicity on biochemical changes and accumulation of lead in muscle and visceral organs of $O$. niloticus.

\section{Material and Methods}

\section{Determination of $96 \mathrm{hr}$. $\mathrm{LC}_{50}$ according to (Behreus and Karbeur.,} 1953 ).

Sixty apparently healthy $O$. niloticus $($ O. niloticus $)(30 \pm 10 \mathrm{~g}$ ) were collected from fish farm of Central Laboratory for fish Research. Fish were acclimatized for two weeks and were fed on normal basal diet at rate of $3 \%$ of body weight daily. Fish were divided into 5 groups each group contain two aquaria each one contain 6 fish. Each group exposed to different dose of lead acetate for $96 \mathrm{hr}$. Mortality was reported daily for calculation of $96 \mathrm{~h} . \mathrm{LC}_{50}$.

\section{Plant ,fish and experimental design:}

One kilogram of Ceratonia siliqua pods(carob) and other from ficus carica (fig) fruits were collected from market then crushed each one alone, seeds were separated, washed, dried and grinded until a fine powder was obtained. The powder was solved in two liter of ethyl alcohol $100 \%$ for $48 \mathrm{~h}$.with periodical shaking.After $48 \mathrm{~h}$. the extract was fitered by using gauze and funnel.Evaporation of ethyl alcohol by rotator 
evaporator, then the extract was lyophilized after releaseing from evaporator. The lyophilized sample semisolid mass was collected and stored in air tight containers and kept in refrigerator at $4 \mathrm{C}^{\circ}$. The yield was $100 \mathrm{~g}$. The extraction was done according to (Mokhtari et al., 2012).

One hundred and forty healthy fish of $O$. niloticus weight 30-40 g each were collected from fish farm of Central Laboratory for Aquaculture Research Abbassa Sharkia Egypt and acclimatized for two weeks before being used in the experimental study and fed pellets at rate of 3\% of weight daily .They were divided into 7 groups each group contain two aquarim each one contain 10 fish.Fish exposed to two doses of lead acetate $\left(1 / 2\right.$ and $\left.1 / 4 \mathrm{LC}_{50}\right)$ for 90 days. Groups 1,2 and 3 fed a control diet.Groups 4 and 5 fed a diet enriched with $600 \mathrm{mg}$ of carob ether extract $/ \mathrm{kg}$. Groups 6 and 7 fed a diet enriched with $600 \mathrm{mg}$ of fig ether extract $/ \mathrm{kg}$. $(\mathrm{Pb}=$ lead, $\mathrm{C}=$ carob and $\mathrm{F}=$ fig $)$.

\section{Biochemical analysis:}

Blood samples were collected from caudal vein of fish by sterile syringe using EDTA solution as anticoagulant at 30,60 and 90 days .Plasma was obtained by centrifugation and non haemolyzed plasma was stored in deep freezer for biochemical analysis.AST and ALT was determined using liver enzymes kits according to ( Tietz 1967). Plasma urea and creatinine determined using kits according to (Kaplan 1984). Lead accumulation determined according to (A.O.A.C.,1990).

\section{Statistical analysis:}

One way analysis of variance (ANOVA), followed by Tukey's Honestly Significant Difference (Tukey's HSD) test as post hoc test was used. Analysis was done using Statistical Package for Social Sciences version 22.0 (IBM Corp., Armonk, NY, USA). Results are reported in means \pm SEM (Standard Error of Mean). The value of $P<0.05$ was used to indicate statistical significance. Analysis was based on the intention to treat population (Logan 2010).

\section{Results}

\section{Lead $96 \mathrm{hr} \mathrm{LC} \mathrm{C}_{50}$ in Nile tilapia}

The results showed that $96 \mathrm{~h} \mathrm{LC}_{50}$ of lead in Nile tilapia was $155 \mathrm{mg} / \mathrm{L}$ (Table, 1).Fish showed abnormal movements in aquarim ,presence of dark and yellow spots on fish, severe congestion of dorsal area and caudal peduncle and severe congestion of all internal organs. 
Table 1: Actual estimation of $96 \mathrm{~h} \mathrm{LC}_{50}$ in Nile tilapia exposed to
different levels of lead acetate.

\begin{tabular}{|c|c|c|c|c|c|c|}
\hline $\begin{array}{c}\text { Groups } \\
(n=6)\end{array}$ & $\begin{array}{c}\text { Concentration } \\
(\mathbf{m g} / \mathrm{L})\end{array}$ & $\begin{array}{c}\text { No of dead } \\
\text { fish at } 96 \\
\text { hours }\end{array}$ & b & $\mathbf{A}$ & $\mathbf{a x b}$ & $\Sigma \mathbf{a x b}$ \\
\hline 1 & $60 \mathrm{mg} / \mathrm{l}$ & 1 & \multirow{3}{*}{$\begin{array}{c}1.5 \\
3\end{array}$} & $60 \mathrm{mg} / \mathrm{l}$ & \multirow[b]{2}{*}{90} & \multirow[b]{4}{*}{510} \\
\hline 2 & $120 \mathrm{mg} / \mathrm{l}$ & 2 & & $60 \mathrm{mg} / \mathrm{l}$ & & \\
\hline 3 & $180 \mathrm{mg} / \mathrm{l}$ & 4 & & $60 \mathrm{mg} / \mathrm{l}$ & 180 & \\
\hline 4 & $240 \mathrm{mg} / \mathrm{l}$ & 4 & 4 & $60 \mathrm{mg} / \mathrm{l}$ & 240 & \\
\hline
\end{tabular}

The formula of calculation was: $96 \mathrm{~h} \mathrm{LC50=highest} \mathrm{dose-} \Sigma$ axb/n (a=Constant factors between two successive dose, $\mathrm{b}=$ the mean of dead fish in each group, $\Sigma \mathrm{axb}=$ sum of axb, $\mathrm{n}=$ Number of fish in each groups) $=240-510 / 6=155 \mathrm{mg} / \mathrm{L}$.

Data in table (2) showed that the AST activity in $O$. niloticus in control group (145.93 $\pm 4.56,161.53 \pm 3.39$ and 159.28 \pm 8.9$)$ at 30 ,60 and 90 days. Also the AST in O. niloticus exposed to $1 / 2$ and $1 / 4 \mathrm{LC}_{\mathbf{5 0}}$ of lead acetate and fed a control diet or fed adiet enriched with $600 \mathrm{mg}$ of carob $/ \mathrm{kg}$ was significantly increased $(\mathrm{p}<.05)$ when compared with the control group at 30,60 and 90 days. While the AST activity in $O$. niloticus exposed to $1 / 2$ and $1 / 4 \mathrm{LC}_{\mathbf{5 0}}$ of lead acetate and fed with diet contain $600 \mathrm{mg}$ of fig $/ \mathrm{kg}$ was non significant changes $(\mathrm{p}<.05)$ when compared with the control group at 30,60 and 90 days.

Table (2) also showed that the ALT activity in $O$. niloticus in control group $(3.44 \pm 0.21,3.52 \pm 0.37$ and 3.92 \pm 0.65$)$ at 30,60 and 90 days. Also the ALT in O. niloticus exposed to $1 / 2$ and $1 / 4 \mathrm{LC}_{50}$ of lead acetate and fed a control diet or fed adiet enriched with $600 \mathrm{mg}$ of carob $/ \mathrm{kg}$ was significantly increased $(\mathrm{p}<.05)$ when compared with the control group at 30,60 and 90 days. While the ALT activity in O. niloticus exposed to $1 / 2$ and $1 / 4 \mathrm{LC}_{\mathbf{5 0}}$ of lead acetate and fed with diet contain $600 \mathrm{mg}$ of fig $/ \mathrm{kg}$ was non significant changes $(\mathrm{p}<.05)$ when compared with the control group at 60 and 90 days.

The plasma urea level of $O$. niloticus in control group was $(3.07 \pm 0.44$, $3.5 \pm 0.39$ and $2.85 \pm 0.11 \mathrm{mg} / \mathrm{dl}$ ) after 30,60 and 90 days, respectively (table,3).It indicated that exposure of $O$. niloticus to $1 / 2$ and $1 / 4 \mathrm{LC}_{\mathbf{5 0}}$ of $\mathrm{Pb}$ and fed a control diet or diet enriched with $600 \mathrm{mg}$ of carob $/ \mathrm{kg}$ induced a significant increase in plasma urea level when compared with 
the control group at 30,60 and 90 days. While fish exposed to $1 / 2$ and $1 / 4$ $\mathrm{LC}_{50}$ of $\mathrm{Pb}$ and fed a diet enriched with $600 \mathrm{mg}$ fig $/ \mathrm{kg}$ showed significant increase after 30 days while no significant changes $(p<.05)$ in plasma urea levesl when compared with control group at 60 and 90 days.

The plasma creatinine level of $O$. niloticus in control group was $(0.25 \pm 0.06,0.21 \pm 0.01$ and $0.24 \pm 0.06 \mathrm{mg} / \mathrm{dl})$ after 30,60 and respectively 90 days, (table,3).It demonstrated that exposure of $O$. niloticus to $1 / 2$ and $1 / 4 \mathrm{LC}_{50}$ of $\mathrm{Pb}$ and fed a control diet induced a significant increase in plasma creatinine level when compared with control group at 30,60 and 90 days. Also showed that exposure of $O$. niloticus to $1 / 2$ and $1 / 4 \mathrm{LC}_{50}$ of $\mathrm{Pb}$ and fed with diet contain $600 \mathrm{mg}$ of carob or fig $/ \mathrm{kg}$ showed no significant changes $(p<.05)$ in plasma creatinine level when compared with control group at 60 and 90 days .

In table (4), showed that the lead concentrations in muscle of $O$. niloticus was $0.68 \pm 0.17,0.65 \pm 0.17$ and $0.61 \pm 0.35 \mathrm{ppm}$ in control group at 30,60 and 90 days, respectively. It revealed that muscle of $O$. niloticus exposed to $1 / 2$ and $1 / 4 \mathrm{LC}_{\mathbf{5 0}}$ of lead acetate and fed a control diet was a significantly increased $(\mathrm{p}<.05)$ in lead concentration when compared with the control group at 30,60 and 90 days. While muscle of O. niloticus exposed to $1 / 4 \mathrm{LC}_{\mathbf{5 0}}$ of lead acetate and fed a diet enriched with $600 \mathrm{mg}$ carob or fig ether extract $/ \mathrm{kg}$ was no significant changes $(\mathrm{p}<.05)$ in lead concentration for 30 days when compared with the control group.

The lead concentration in visceral organs of $O$. niloticus was $9.68 \pm 2.29,9.81 \pm 2.43$ and $9.98 \pm 2.51 \mathrm{ppm}$ in control group at 30,60 and 90 days, respectively (table,4).It revealed that visceral organs of Oreochromis niloticus exposed to $1 / 2$ and $1 / 4 \mathrm{LC}_{\mathbf{5 0}}$ of lead acetate and fed a control diet was a significantly increased $(p<.05)$ in lead concentration when compared with the control group at 30, 60 and 90 days. While visceral organs of $O$. niloticus exposed to $1 / 4 \mathrm{LC}_{\mathbf{5 0}}$ of lead acetate and fed a diet enriched with $600 \mathrm{mg}$ carob or fig ether extract $/ \mathrm{kg}$ was no significant changes $(p<.05)$ in lead concentration for 30 days when compared with the control group. 
Table (2): Changes in aspartate amino transferase(AST) and alanine amino transferase (ALT) IU/L in the plasma of Oreochromis niloticus exposed to two doses of lead acetate and fed on a diet enriched with carob or fig after thirty, sixty and ninety days of exposure :

\begin{tabular}{|c|c|c|c|c|c|c|}
\hline & \multicolumn{3}{|c|}{ AST } & \multicolumn{3}{|c|}{ ALT } \\
\hline $\begin{array}{l}\text { Days } \\
\text { Groups }\end{array}$ & 30d & 60d & 90d & 30d & 60d & 90d \\
\hline Control & $145.93 \pm 4.56^{\mathbf{b}}$ & $161.53 \pm 3.39^{\mathbf{b}}$ & $159.28 \pm 8.9^{\mathbf{c}}$ & $3.44 \pm 0.21^{\mathrm{d}}$ & $3.52 \pm 0.37^{\mathbf{c}}$ & $3.92 \pm 0.65^{\mathbf{c}}$ \\
\hline $1 / 2 \mathrm{LC}_{50} \mathrm{~Pb}$ & $165.43 \pm 6.2^{\mathbf{a}}$ & $178 \pm 2.78^{\mathrm{a}}$ & $199.11 \pm 6.18^{\mathrm{a}}$ & $7.92 \pm 0.89^{\mathrm{a}}$ & $8.4 \pm 0.22^{\mathrm{a}}$ & $9.16 \pm 0.62^{\mathrm{a}}$ \\
\hline $1 / 4 \mathrm{LC}_{50} \mathrm{~Pb}$ & $156.66 \pm 7.13^{\mathrm{a}}$ & $170.59 \pm 9.71^{\mathrm{a}}$ & $172.76 \pm 4.46^{\mathbf{b}}$ & $6.72 \pm 0.31^{\mathrm{a}}$ & $7.68 \pm 0.42^{\mathrm{a}}$ & $8.55 \pm 0.52^{\mathrm{a}}$ \\
\hline $1 / 2 \mathrm{LC}_{50}+\mathrm{C}$ & $169.62 \pm 6.62^{a}$ & $173.95 \pm 2.12^{\mathrm{a}}$ & $183.24 \pm 8.33^{\mathbf{b}}$ & $5.2 \pm 0.72^{\mathbf{b}}$ & $6.96 \pm 0.13^{b}$ & $7.32 \pm 0.88^{\mathbf{b}}$ \\
\hline $1 / 4 \mathrm{LC}_{50}+\mathrm{C}$ & $166.9 \pm 6.79^{\mathrm{a}}$ & $172.5 \pm 9.25^{\mathrm{a}}$ & $179 \pm 7.5^{b}$ & $5.12 \pm 0.57^{\mathbf{b}}$ & $5.66 \pm 0.11^{b}$ & $6.16 \pm 0.74^{b}$ \\
\hline $1 / 2 \mathrm{LC}_{50}+\mathrm{F}$ & $144.32 \pm 2.47^{\mathbf{b}}$ & $162.29 \pm 2.58^{\mathbf{b}}$ & $160.22 \pm 4.04^{\mathrm{c}}$ & 4. $6 \pm 0.38^{\mathrm{c}}$ & $4.46 \pm 0.24^{\mathrm{c}}$ & $3.9 \pm 0.61^{\mathrm{c}}$ \\
\hline $1 / 4 \mathrm{LC}_{50}+\mathrm{F}$ & $143.86 \pm 6.7^{\mathbf{b}}$ & $155.13 \pm 3.39^{\mathbf{c}}$ & $157.82 \pm 4.24^{\mathrm{c}}$ & $4.36 \pm 0.57^{\mathrm{c}}$ & $3.88 \pm 0.2^{\mathbf{c}}$ & $3.87 \pm 0.55^{\mathbf{c}}$ \\
\hline
\end{tabular}

Means within the same column carrying different superscripts are sig. different at $\mathrm{P}<0.05$ based on Tukey's Honest ly Significant Difference (Tukey's HSD) test. $(\mathrm{Pb}=$ lead, $\mathrm{C}=$ carob and $\mathrm{F}=$ fig $)$. 
Table (3): Changes in urea and creatinine level (mg/dl ) in the plasma of Oreochromis niloticus exposed to two doses of lead acetate and fed on a diet enriched with carob ether extract or fig ether extract after thirty, sixty and ninety days of exposure :

\begin{tabular}{|c|c|c|c|c|c|c|}
\hline & \multicolumn{3}{|c|}{ Urea } & \multicolumn{3}{|c|}{ Creatinine } \\
\hline Groups & 30d & 60d & 90d & 30d & $60 d$ & 90d \\
\hline Control & $3.07 \pm 0.44^{\mathrm{c}}$ & $3.5 \pm 0.39^{c}$ & $2.85 \pm 0.11^{\mathrm{c}}$ & $0.25 \pm 0.06^{\mathbf{b}}$ & $0.21 \pm 0.01^{\mathbf{b}}$ & $0.24 \pm 0.06^{\mathbf{b}}$ \\
\hline $1 / 2 \mathrm{LC}_{50} \mathrm{~Pb}$ & $8.73 \pm 0.41^{\mathrm{a}}$ & $8.83 \pm 0.24^{\mathrm{a}}$ & $9.82 \pm 0.93^{\mathrm{a}}$ & $0.35 \pm 0.03^{\mathrm{a}}$ & $0.43 \pm 0.07^{\mathrm{a}}$ & $0.53 \pm 0.05^{\mathrm{a}}$ \\
\hline $1 / 4 \mathrm{LC}_{50} \mathrm{~Pb}$ & $7.15 \pm 0.11^{\mathrm{a}}$ & $8.34 \pm 0.28^{\mathrm{a}}$ & $8.36 \pm 0.76^{\mathrm{a}}$ & $0.31 \pm 0.08^{\mathrm{a}}$ & $0.38 \pm 0.09^{a}$ & $0.46 \pm 0.04^{\mathrm{a}}$ \\
\hline $1 / 2 \mathrm{LC}_{50}+\mathrm{C}$ & $7.34 \pm 0.17^{\mathbf{a}}$ & $5.47 \pm 0.38 b$ & $4.9 \pm 0.38^{\mathbf{b}}$ & $0.35 \pm 0.02^{\mathrm{a}}$ & $0.25 \pm 0.04^{\mathbf{b}}$ & $0.27 \pm 0.05^{\mathbf{b}}$ \\
\hline $1 / 4 \mathrm{LC}_{50}+\mathrm{C}$ & $6.1 \pm 0.51^{\mathbf{b}}$ & $4.26 \pm 0.17 b$ & $4.12 \pm 0.22^{\mathbf{b}}$ & $0.21 \pm 0.09^{\mathbf{b}}$ & $0.23 \pm 0.08^{\mathbf{b}}$ & $0.24 \pm 0.05^{\mathbf{b}}$ \\
\hline $1 / 2 \mathrm{LC}_{50}+\mathrm{F}$ & $8.32 \pm 1.05^{\mathrm{a}}$ & $3.74 \pm 0.08^{\mathrm{c}}$ & $3.38 \pm 0.5^{\mathbf{c}}$ & $0.28 \pm 0.01^{\mathbf{b}}$ & $0.21 \pm 0.06^{\mathbf{b}}$ & $0.32 \pm 0.03^{\mathbf{b}}$ \\
\hline $1 / 4 \mathrm{LC}_{50}+\mathrm{F}$ & $7.87 \pm 0.83^{\mathrm{a}}$ & $3.22 \pm 0.71^{\mathrm{c}}$ & $3.2 \pm 0.57^{\mathrm{c}}$ & $0.25 \pm 0.09^{b}$ & $0.18 \pm 0.08^{\mathbf{b}}$ & $0.24 \pm 0.05^{\mathbf{b}}$ \\
\hline
\end{tabular}

Means within the same column carrying different superscripts are sig. different at $\mathrm{P}<0.05$ based on Tukey's Honestly Significant Difference (Tukey's HSD) test. . $(\mathrm{Pb}=$ lead, $\mathrm{C}=$ carob and $\mathrm{F}=$ fig $)$. 
Table (4): Lead concentration (ppm.) in the muscle and visceral organs of Oreochromis niloticus exposed to two doses of lead acetate and fed on a diet enriched with carob ether extract or fig ether extract after thirty, sixty and ninety days of exposure :

\begin{tabular}{|c|c|c|c|c|c|c|}
\hline \multirow{2}{*}{ Groups } & \multicolumn{3}{|c|}{ Muscle } & \multicolumn{3}{|c|}{ Visceral organs } \\
\hline & 30d & $60 d$ & 90d & 30d & $60 d$ & 90d \\
\hline Control & $0.68 \pm 0.17^{\mathbf{d}}$ & $0.65 \pm 0.15^{\mathrm{c}}$ & $0.61 \pm 0.14^{\mathbf{b}}$ & $9.68 \pm 2.29^{d}$ & $9.81 \pm 2.43^{d}$ & $9.98 \pm 2.51^{d}$ \\
\hline $1 / 2 \mathrm{LC} \mathrm{C}_{50} \mathrm{~Pb}$ & $3.19 \pm 0.4^{\mathrm{a}}$ & $3.66 \pm 0.41^{\mathrm{a}}$ & $6.56 \pm 0.24^{\mathrm{a}}$ & $38.43 \pm 2.69^{\mathrm{a}}$ & $97.56 \pm 2.35^{\mathbf{b}}$ & $99.44 \pm 2.62^{b}$ \\
\hline $1 / 4 \mathrm{LC}_{50} \mathrm{~Pb}$ & $2.11 \pm 0.15^{\mathbf{b}}$ & $2.67 \pm 0.4^{\mathrm{a}}$ & $4.76 \pm 0.73^{\mathrm{a}}$ & $34.42 \pm 3.1^{\mathrm{a}}$ & $95.28 \pm 6.53^{\mathbf{b}}$ & $98.26 \pm 1.58^{\mathbf{b}}$ \\
\hline $1 / 2 \mathrm{LC}_{50}+\mathrm{C}$ & $0.9 \pm 0.19^{\mathbf{c}}$ & $1.13 \pm 0.17^{\mathbf{b}}$ & $9.92 \pm 0.41^{\mathrm{a}}$ & $32.57 \pm 4.71^{\mathrm{a}}$ & $59.27 \pm 2.21^{\mathrm{c}}$ & $98.58 \pm 6.52^{\mathbf{b}}$ \\
\hline $1 / 4 \mathrm{LC}_{50}+\mathrm{C}$ & $0.78 \pm 0.16^{\mathbf{d}}$ & $0.91 \pm 0.22^{\mathbf{b}}$ & $5.6 \pm 0.9^{\mathrm{a}}$ & $12.89 \pm 3.86^{\mathrm{d}}$ & $45.47 \pm 2.48^{\mathrm{c}}$ & $94.9 \pm 2.01^{b}$ \\
\hline $1 / 2 \mathrm{LC}_{50}+\mathrm{F}$ & $1.02 \pm 0.4^{\mathrm{c}}$ & $1.47 \pm 0.14^{\mathbf{b}}$ & $6.1 \pm 0.25^{\mathrm{a}}$ & $33.33 \pm 3.35^{\mathrm{a}}$ & $43.83 \pm 1.94^{c}$ & $97.11 \pm 4.25^{\mathbf{b}}$ \\
\hline $1 / 4 \mathrm{LC}_{50}+\mathrm{F}$ & $0.88 \pm 0.19^{d}$ & $1.09 \pm 0.14^{\mathbf{b}}$ & $5.07 \pm 0.17^{\mathbf{a}}$ & $10.95 \pm 3.69^{d}$ & $13.76 \pm 2.73^{d}$ & $59.16 \pm 3.8^{c}$ \\
\hline
\end{tabular}

Means within the same column carrying different superscripts are sig. different at $\mathrm{P}<0.05$ based on Tukey's Honestly Significant Difference (Tukey's HSD) test. . $(\mathrm{Pb}=$ lead, $\mathrm{C}=$ carob and $\mathrm{F}=$ fig). 


\section{Discussion}

Medicinal plants are natural resources yielding valuable herbal products which are often used in the treatment of various ailments (Grabley and Thiericke, 1999). Medicinal plants have become the focus of intensive study recently in terms of conservation and as to whether their traditional uses are supported by actual pharmacological effects (Sokovic et al .,2004).

Our study showed that Oreochromis niloticus fed with diet contain carob extract $600 \mathrm{mg} / \mathrm{kg}$ and exposed to $1 / 2$ and $1 / 4 \mathrm{LC}_{50}$ of $\mathrm{Pb}$ showed improvement in plasma creatinine and lead accumulation in muscle. while in that fed a diet enriched with fig extract $600 \mathrm{mg} / \mathrm{kg}$ showed improvement in creatinine, urea, AST, ALT and lead accumulation in muscle.

Hepatic cells participate in avariety of metabolic activities and contain enzymes which have been used as a markers for monitoring chemically liver damage. The enzymes AST and ALT activities are important enzymes that are often increased in liver injury (Hukkeri et al., 2002). In this study $O$. niloticus exposed to $1 / 2$ and $1 / 4 \mathrm{LC}_{50}$ of $\mathrm{Pb}$ and fed control diet showed a significant increase in AST and ALT after thirty, sixty and ninety days of exposure this is a marker for loss of functional integrity of cell membrane of hepatocytes ,hepatic damage and damage of liver cell lead to leakage of enzymes . This decrease resulted from the deleterious effect of the toxin on the hepatic cell wall. This study supported by ( Elgaml et al., 2015) who found hepatic toxicity of lead acetate in $O$. niloticus revealed an increase in the levels of liver enzymes. Also this study in agreement with (Shalaby 2006 and 2007 ) who found that exposure of $O$. niloticus to heavy metals caused significantly increased in AST and ALT enzymes.

Results of this study clearly showed an improvement in activities of AST, ALT in O. niloticus exposed $1 / 2$ and $1 / 4 \mathrm{LC}_{50}$ of $\mathrm{Pb}$ and fed a diet enriched with $600 \mathrm{mg}$ of fig $/ \mathrm{kg}$ after thirty, sixty and ninety days of exposure. These results go hand in hand with those of (Aghel $\boldsymbol{e t}$ al., 2011) in which different doses of ficus carica extract (200, 400 and $800 \mathrm{mg} / \mathrm{kg}$ ) prior to intoxication with $\mathrm{ccl}_{4}$ showed decreased activities of AST and ALT enzymes. Fig protected the liver from the deleterious effect of the toxin which cause damage of hepatocyte, and keep the integrity of hepatic cell wall and prevent leakage of enzymes. 
In this study $O$. niloticus exposed to $1 / 2$ and $1 / 4 \mathrm{LC}_{50}$ of $\mathrm{Pb}$ and fed control diet showed a significant increase in plasma urea and creatinine after 30,60 and 90 days of exposure. This study is supported by ( Elgaml et al., 2015) who found renal toxicity of lead acetate in $O$. niloticus revealed by an increase in the levels of urea and creatinine. An increase in the urea and creatinine levels might be due to the glomerular insufficiency, also the increase in the production of reactive oxygen species and kidney injury as a result of $\mathrm{Pb}$ induced nephrotoxicity. The elevation of urea and creatinine levels in the blood is an indicative of impaired kidney function.

Results of this study clearly demonstrated a significant decrease in plasma creatinine in O. niloticus exposed to lead $1 / 2$ and $1 / 4 \mathrm{LC}_{50}$ of $\mathrm{Pb}$ and fed a diet enriched with $600 \mathrm{mg}$ carob or fig $/ \mathrm{kg}$ after sixty and ninety days of exposure. While plasma urea decreased in fish fed on a diet enriched with fig ether extract $600 \mathrm{mg} / \mathrm{kg}$ only at 60,90 days. This may be due to ameliorative effect of fig on the kidney function and the antioxidant effect of carob and fig in scavenging $\mathrm{Pb}$ induced free radicals.

In this study $O$. niloticus exposed to $1 / 2$ and $1 / 4 \mathrm{LC}_{50}$ of $\mathrm{Pb}$ and fed control diet showed a significant increase in lead concentration in muscle and visceral organs after 30,60 and 90 days of exposure. Our study also showed that muscle and visceral organs of $O$. niloticus exposed to $1 / 4$ $\mathrm{LC}_{\mathbf{5 0}}$ of lead acetate and fed diet contain $600 \mathrm{mg}$ of carob or fig $/ \mathrm{kg}$ revealed improvement by decrease in lead concentration when compared with the control group at 30 days. Our study supported by (Bosscher $\boldsymbol{e t}$ al., 2001) that carob interfered with the absorption of lead.Also supported by (Aziz 2012 ) who reported that fig is achelating agent for lead acetate.

\section{Conclusion}

The results of this study proved that carob (Ceratonia siliqua) pods and fig (Ficus carica) fruits ether extracts have possible positive impact against lead toxicity in tilapia nilotica (O. niloticus). Summing up our observation, carob (Ceratonia siliqua) improve creatinine level, decrease lead accumulation in muscle. While fig ( Ficus Carica) keep the kidney functions and decrease lead accumulation in muscle. So our study recomend addition of carob and fig ether extracts to fish diet as herbal medicine to keep and improve biological processes of fishes and to reduce lead accumulation in fishes. Further studies should be done. 
Biochemical studies in Oreochromis niloticus exposed to lead acetate and treated by carob or fig ether extracts

\section{References}

Adedeji, O.S.; Farimi, G.O.; Ameen, S.A. and Olayemi, J.B. (2006): Effects of bitter kola ( Garcinial kola) as growth promoter in Broiler Chicks from day old to four weeks old. J. Anim. Vet. Adv.5(3): 191193.

Aghel, N.; Kalantari, H. and Rezazadeh S.(2011): Hepatoprotective Effect of Ficus carica Leaf Extract on Mice Intoxicated with Carbon Tetrachloride. Iranian Journal of Pharmaceutical Research . 10 (1): 6368.

A.O.A.C.(1990):Association of OAC .Official methods of analysis 15 th ed.vol.1.Arlington, Virginia USA.247PP.

Aziz, F.M.(2012): Protective effects of latex of Ficus carica L. against lead acetate induced hepatotoxicity in rats. Jordan Journal of Biological Sciences Volume 5, Number 3, Pages 175 - 182. ISSN 1995-6673.

Behreus, A.S. and Karbeur L. (1953): Determination of LC50.Arch Exp. Path. Pharm., 28:177-183.

Bosscher, D.; Caillie, B. M. and Deelstra H.(2001): Effect of thickening agents, based on soluble dietary fiber, on the availability of calcium, iron, and zinc from infant formulas. Nutrition .17(7-8):614-618.

Citarasu, T.( 2010): Herbal biomedicines a new opportunity for aquaculture industry. Aquaculture International, 18: 403-414.

Elgaml, A.S.; Khalil, R.; Hashish, A.E. and El Murr A.(2015): Protective effects of selenium and alpha tocopherol against lead induced hepatic and renal toxicity in Oreochromis Niloticus. J Aquac Res Development 2015, 6:1.

Grabley, S. and Thiericke R.(1999): The impact of natural products on drug discovery, Drug discovery from nature, Springer, Berlin.

Hukkeri, V.I.; Jaiprakash, B.; Lavhale, M.S.; Karadi, R.V. and Kuppast, I.J. (2002): Hepatoprotective activity of anthus excels roxb.leave extracts on experimental liver damage in rats.J Pharmacogn.,11:120128.

Jackie, T.; Haleagrahara, N. and Chakravarthis (2011): Antioxidant effects of Etlingera elatior flower extract against lead acetate induced perturbations in free radical scavenging enzymes and lipid peroxidation in rats. BMC Research Notes. 4:67-75. 
Kaplan, A. (1984): Clin. Chem. The C. V. Mosby Co. St Louis. Toronto. Princeton.1257-1260-1032-1036 and437and 418.

Krishna, M. G.; Pallavi, E.; Ravi Kumar, B.; Ramesh, M. and Venkatesh S. (2007): Hepatoprotective activity of Ficus carica Linn. leaf extract against carbon tetrachloride induced hepatotoxicity in rats. DARU 15( 3 ). $162-166$.

Kumar, A.(2012):Areview on hepatoprotective herbal drugs.International Journal of research in pharmacy and chemistry.2(1):2231-2781.

Logan, M. (2010): Biostatistical design and analysis using r: a practical guide. Wiley- Blackwell, London. p.546.

Mokhtari, M.; Sharifi, E. and Azadian S.h. (2012): The effects of hydro alcoholic extract of Ceratonia siliqua L. seeds on pituitary testis hormones and spermatogenesis in rat. Environmental Biology, 6(10): 2778-2783.

Roy, S.D; Das, S.; Shil, D. and Dutta K.N.(2012):Herpal hepatoprotective agents. World Journal of Pharmaceutical research. 1,( 2),87-99.

Shalaby, A.M.E.(2006):Reproductive and patho-physiological responses of blue tilapia (Oreochromis aureus) exposed to chromium with or without chelating substances.Egypt.J.Exp.Biol.(Zool.),2:195-206.

Shalaby, A.M.E.(2007): Effect of EDTA on toxicity reduction of cadmium in relation to growth ,some haematological and biochemical profiles of Nile tilapia (Oreochromis niloticus).Journal of Fisheries and Aquatic Science.2(2):100-109.

Sharma, R.P. and Street, J.C.(1980): Public health aspects of toxicheavy metals in animal feeds. J of the Amer Veter. Med. Ass. 177(2):149153.

Sokovic, M..D.; Ristic, M. and Grubisic, D. (2004): Chemical composition and antifungal activity of the essential oil from Juniperus excelsa Berries. Pharmacologica Biology . 42: 328-331.

Tapsell, L.C. and cobiac, L.(2006): Health benefits of herbs and spices the past, the present and the future. Med.J.Aust.185(4). S4-24.

Tietz, N.W.(1967): Fundamentals of clinical chemistry W.B.Saunders CO,Philadelphia. 


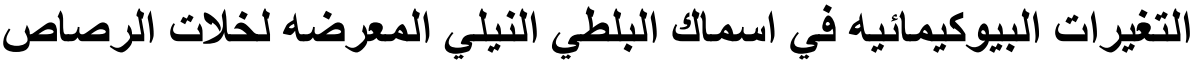

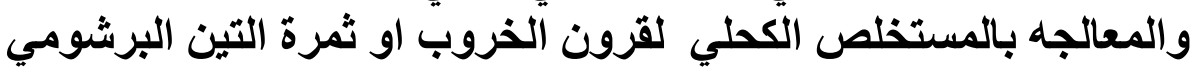

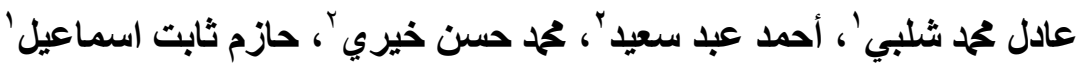
'قسم فسيولوجيا الاسماك المعمل المركزى لبحوث الثروة السمكيه، العباسة، ابو حماد، الثرقية، مصر. "قَم الفارماكولوجيا، كلية الطب البيطري، جامعة الزقازيق، مصر. الملخص العربي

استهدف هذا البحث دراسة تأثثر المستخلص الكحولي لقرون الخروب اوثمرة التين

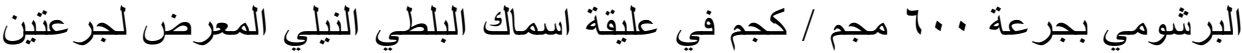

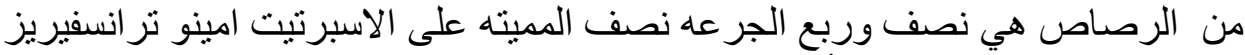

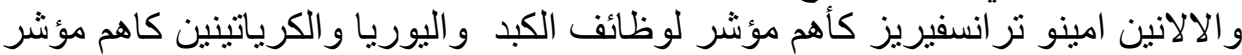

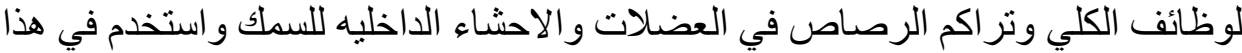

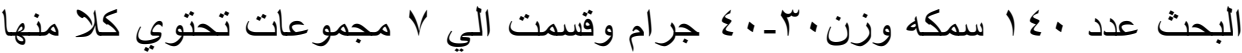

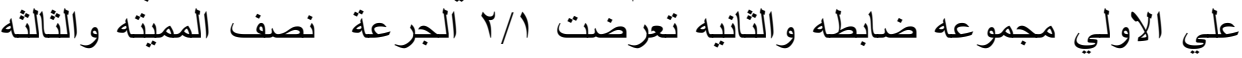

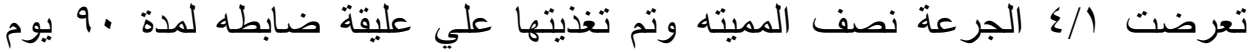

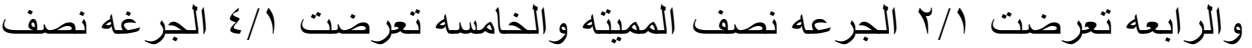

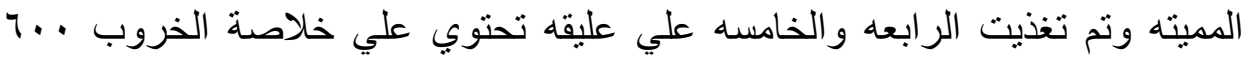

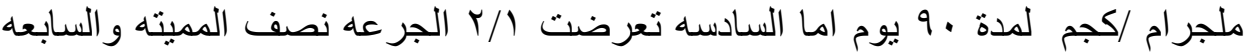

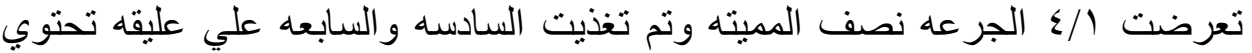

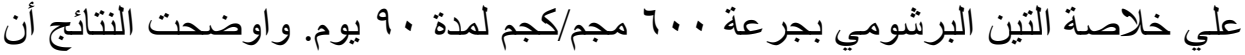

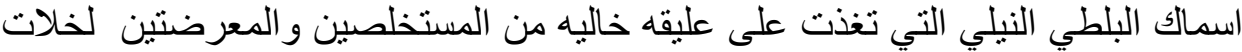

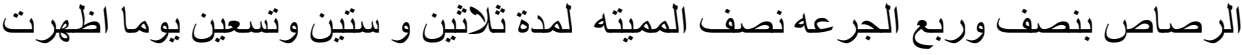

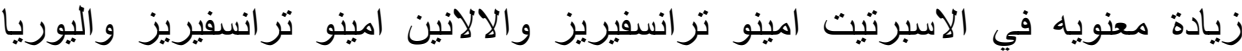

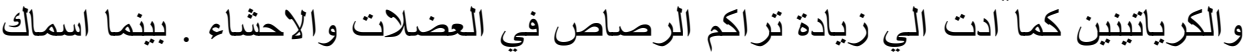

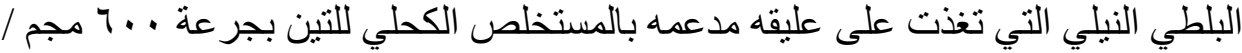

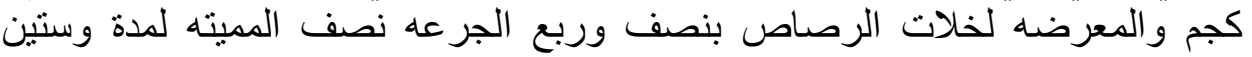

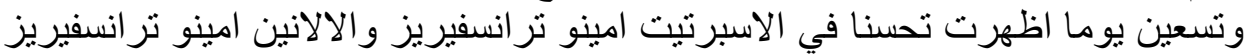

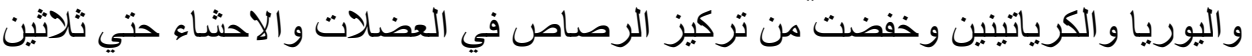

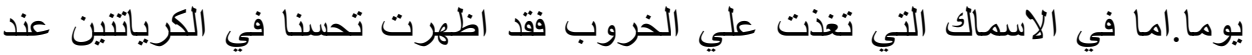
ستون وتسعون يوما وادت الي انخفاض الرصاص الترو في العضلات والاحشاء حتي ثلاثين 